\title{
The quest for status: how the interplay of power, ideas, and regime security shapes Russia's policy in the post-Soviet space
}

\author{
Maria Raquel Freire ${ }^{1}$
}

(C) Macmillan Publishers Ltd., part of Springer Nature 2018

\begin{abstract}
The aim of this article is to analyze how power, ideas, and domestic factors contribute to Russia's goal of status recognition. The article focuses in particular on Moscow's policies and actions in the post-Soviet area. Toward this end, it looks at recent developments in Russia's policy toward Ukraine, including the developments leading to the annexation of Crimea and events after the signing of the Minsk II agreement. Relatedly, it also addresses the formation of the Eurasian Economic Union. Finally, it looks at Moscow's policy toward Georgia since the 2008 war. In short, the article seeks to understand how Russia's status ambitions-underpinned by power politics, ideas, and domestic factors - shape its foreign policy behavior in the post-Soviet area.
\end{abstract}

Keywords Russia $\cdot$ Status $\cdot$ Power $\cdot$ Ideas $\cdot$ Regime security

\section{Introduction}

Russian foreign policy has consistently reaffirmed the country's drive to achieve and hold status in its relation vis-à-vis the West (see, e.g., Freire 2011; Neumann 2008; Tsygankov 2014). This article argues that Russia's status ambitions are partly driven by power, partly by ideational factors, and partly by regime security considerations. These intertwined readings of power, status, and ideas have been a constant in Russian foreign policy, particularly after Putin's arrival to the presidency in 2000. Russian foreign policy documents have consistently described Russia as a relevant player, pursuing policies 'to achieve firm and prestigious positions in the

Maria Raquel Freire

rfreire@fe.uc.pt

1 FEUC, Av Dias da Silva 165, 3004-512 Coimbra, Portugal 
world community, most fully consistent with the interests of the Russian Federation as a great power, as one of the most influential centres of the modern world' (RFP 2000), underlining 'its status as one of the leading States of the world' (RFP 2008) and 'Russia's increased responsibility for setting the international agenda and shaping the system of international relations' (RFP 2013), and proposing to advance 'the Russian Federation's position as a centre of influence in today's world' (RFP 2016). This quest for status recognition permeates Moscow's international activities, leading to a foreign policy that has proven to be both advantageous and costly for Russia.

The aim of this article is to analyze how power, ideas, and domestic factors contribute to Russia's quest for status recognition, which in turn shapes its neighborhood policy. Toward that end, the article looks at recent developments in Moscow's policy toward Ukraine, including the developments leading to the annexation of Crimea and events after the signing of the Minsk II agreement. Relatedly, it also addresses the formation of the Eurasian Economic Union. Finally, it looks at Moscow's policy toward Georgia after the 2008 war. The analysis is informed by two main trends in foreign policy studies: firstly, the interconnection between the international and the domestic in foreign policymaking (see, e.g., Putnam 1988; Evangelista 1997; Saideman and Ayres 2007); and secondly, the need to look at both material and ideational aspects (see, e.g., Hill 2003; Neack 2008). These two trends are interconnected as the material/ideational basis of foreign policymaking takes place at the 'intermestic'- that is, at the intersection of the international and the domestic (Manning 1977).

In brief, the argument put forth in the article is that Russia's pursuit of status serves an outward function, namely to affirm the country's standing as a global player with capacity to influence major developments on the world stage. At the same time, it also serves an internal function as the policies and actions underpinning the projection of a great-power image feed into domestic discourses. This relates to the inward function associated with domestic politics, centered mainly on generating support for the Putin government. Following this framework of analysis, power politics, national identity, and regime security are identified as central components that underpin Russia's quest for status recognition. The aim of the article is, thus, to grasp how these three elements shape Russia's foreign policy in the postSoviet area.

\section{Status: power politics, national identity and regime security}

Status ambitions in Russian foreign policy reflect a combination of geopolitical, ideational, and normative aspects, which intertwine in the shaping and making of policies. These three components reflect both the internal/external dynamics and the material/ideational nexus in foreign policymaking. 
First, power politics underlines the goal of recognition of Russia as a great power, involving a strong military-defense component. ${ }^{1}$ The perceived need for self-defense against a policy of Western encirclement has been emphasized repeatedly in Russian policy documents, with the enlargement of the North Atlantic Treaty Organization (NATO) constituting a main threat (RFP 2016; Military Doctrine 2014). Moreover, the repositioning of Russia as a major power with prevailing influence in the postSoviet space has been sought both in territorial terms (annexation of Crimea) and on the basis of consolidating its influence in the area. Evidence of the latter is found in security arrangements and other economic and political treaties signed with Abkhazia and South Ossetia. As for Crimea's annexation, this became a demonstration of Russian hard power in a geopolitically driven move, displaying the disposition to use force, if need be, in the attainment of its self-perceived goals. Indeed, Mearsheimer (2014) has argued that international pressures, namely offensive actions of the West and geostrategic imperatives, were the main drivers of Russia's policies toward Ukraine. However, the Black Sea Fleet stationed in the Crimean peninsula was already under Russian control and an agreement was in place until 2042. Arguably, even if the choice to intervene militarily can be understood as rational, the risks associated with it were extremely high (Forsberg and Pursiainen 2017: 224). Moreover, the Russian rhetoric of justifying the 'reintegration' of the Crimean territory on the basis of history and international law (the self-determination of peoples, with the 'responsibility to protect' as a justification) indicates that more than narrower geopolitical interests were at play. All of this suggests that a purely power-political reading of Russian foreign policy limits our understanding of Moscow's choices.

Second, ideational factors have also been an important factor in shaping Russian foreign policy. Russia seeks Western recognition of its great-power status, including through the acknowledgment of its system of values and institutions as legitimate. This indicates that Moscow understands its identity as distinctive. Indeed, an identity-related framing of foreign policy underpins many Russian statements about its place in the international system (Ambrosio 2005: viii). As Tsygankov (2014: 347 ) puts it, 'Russia's identity or sense of honor is not limited to protection of state international status/prestige in the eyes of other states, but also includes a distinctive idea of national self.' This has become increasingly clear in Moscow's foreign policy formulation, such as the last Foreign Policy Concept (approved in 2016), which addresses Russia's uniqueness in the promotion of 'global civilization' (RFP 2016). In other words, ideas about a unique identity and values-set, distinct from a decadent West, permeate the discourse informing the construction of a substantive understanding about status. Moreover, identity permeates the discourse about Russian minorities abroad and how Moscow should reach out to protect and defend their rights and interests when at risk. These identity-based aspects of foreign policy relate to power-driven ones. Together, they allow for a more encompassing understanding of how Russian foreign policy is shaped and conducted.

\footnotetext{
1 According to the SIPRI Report on World Military Spending (2017), Russia increased its military spending by $5.9 \%$ in 2016 to $\$ 69.2$ billion, becoming the third largest spender in the world after the USA and China.
} 
Finally, regime security is also a fundamental dimension in the formation of Russian foreign policy. Two main aspects should be highlighted here: first, that internal consolidation is essential for the acknowledgment of Russia as a main international partner and its affirmation as a major player on the world stage (Trenin 2009; Freire and Simão 2018: 168); and second, that broad-based domestic support for Moscow's foreign policy course is fundamental for internal stability. In this sense, Russia's actions abroad are legitimized by an authoritarian and centralized domestic drive in the country, which builds on the 'powerful president' rhetoric together with normative arguments about Russia's stabilizing role in the international system. This has been visible in the promotion of so-called national interests, from the protection of minority rights to business-related issues. Moreover, several scholars have argued that fears of a 'colored revolution' in Russia (McFaul, cited in Forsberg and Pursiainen 2017: 222; also see Berryman 2014) were part of the motivation for Moscow's actions in Crimea. The wave of popular unrest that swept across the postSoviet space in countries such as Georgia, Ukraine, Kyrgyzstan, and Moldova raised concerns in Russia of similar events potentially threatening the regime. Indeed, Russia's assertive course in Crimea helped President Putin to increase his popularity and consolidate his power at home (The Guardian 2015). ${ }^{2}$ In short, regime security plays an important role in Russian foreign policy, with both the international recognition of Russia's status feeding into the domestic narrative, and the discourse of a strong Russia legitimizing the Kremlin's foreign policy choices. In essence, the three elements-power politics, national identity and regime security-are closely intertwined with the idea of 'great power Russia'.

The goal of projecting the image of a great power works in two ways. First, toward the outer world in Russia's affirmation as an actor with capacity to influence developments in a polycentric system. In Russia's capacity to act, we can identify the three above-mentioned elements: the logic of power politics; ideational elements mainly associated with legitimization as well as the normative discourse underpinning policy options; and regime considerations, which directly feed the image of a great power externally as well as internally. This links to the second aspect: an inwards process associated with status projection. This is visible regarding the consolidation of domestic politics and in keeping a strong support basis for the regime. The latter assures policy-legitimization and reduces space for anti-regime movements. The politics of respect and status recognition are thus central to Russia's international behavior, as further analyzed with regard to its neighborhood policy.

The more assertive and interventionist foreign policy of Russia toward its neighbors has resulted in different approaches. On the one hand, Russia has used coercion and negative measures, including energy pressure through an increase in prices or a decrease in supplies; trade embargos, mainly related to agricultural products; and the use of force as in the cases of Georgia in 2008 and Ukraine in 2014. On the

\footnotetext{
2 Polls conducted by the Levada Centre and the Russian Public Opinion Research Centre (VCIOM) converge on this assessment. VCIOM conducted a survey in December 2017, according to which $83.6 \%$ approve the work of the Russian president (VCIOM 2017). The Levada Centre poll points to a rating of 7/10 of Putin's presidency (Levada Centre 2017).
} 
other hand, Russia has used a positive approach linked to investments in neighboring countries; promoting integration in organizations such as the Eurasian Economic Union; and the signing of preferential contracts in energy terms, for example. In other words, Russia draws on interdependent asymmetries in the post-Soviet space to "keep neighboring countries in its "sphere of influence"" (Ademmer et al. 2016: 10). At the same time, Russia recognizes that it does not hold unlimited power and influence in the post-Soviet space, despite repeatedly referring to the region as a primary area of interest. How Russia's policies toward its neighbors have been developing, and how this reveals the interconnection of the three identified elements in Russian foreign policymaking, is the focus of the next sections.

\section{The game changer: Ukraine}

By the end of 2013, events in Ukraine unfolded at a fast pace. The decision of then President Yanukovych to step back from signing the Association Agreement and Deep and Comprehensive Free Trade Area (DCFTA) with the European Union (EU) in favor of the Customs Union with Russia triggered protests in Kyiv and other Ukrainian cities. Driven by anger about a highly corrupt elite, demonstrations quickly became politicized and ended up embedding the east-west divide inside Ukrainian politics and society. The vote forcing Yanukovych to step down in February 2014 contributed to the escalation of differences, with Russian accusations about a coup. Thus, Moscow refused to recognize the new government in Kyiv. Meanwhile, the swift adoption of a new language law restricting the use of second languages, with clear impact on the use of Russian as second language particularly in Ukraine's eastern regions, further fueled divisions within the country.

When by the end of February 2014 pro-Russian armed forces seized control of government buildings in Simferopol, these divisions became manifest. A referendum was scheduled for March 16 after the Crimean parliament had approved a request to join Russia. The referendum — organized in record time-was overwhelmingly in favor of secession from Ukraine, with the Crimean parliament declaring independence the following day. Despite criticisms about the weak legitimacy of the popular consultation, according to the head of the referendum commission, Mikhail Malyshev, an overwhelming majority of Crimeans chose the Russia option (Reuters 2014a). On March 18, a treaty formalizing Crimea's 'reintegration' (in Moscow's view) into the Russian Federation was signed. Moscow justified the reintegration on the grounds that 'Russian citizens and compatriots' needed protection and because of historical linkages. Moreover, Putin argued that the referendum followed international principles on the right to self-determination and that it was conducted in an open and honest manner with the people of Crimea expressing their will to join Russia (Putin 2014). Together with the 'Novorossiya' idea and slogans such as 'Crimea is ours!', the construction of the 'Russian world' led to the establishment of 'a universal antagonistic border that is constitutive for the whole imaginary community of Russians,' signaling who 'belongs' and who does not 'belong' to this community (Suslov 2017: 203). In other words, the power-political drive that involved the takeover of Crimea was complemented by a legitimizing discourse building on ideational 
issues, where national identity and the sense of belonging were fundamental elements. Thus, when we look at Russia's policy in the case of the unfolding events in Ukraine, it becomes clear that both power politics and identity-related elements underpinned the quest for status recognition.

As Putin put it, Crimea's annexation was an act that brought history into its right place (Putin 2014). This illustrates how the image of a 'great Russia' is a substantive part of Moscow's foreign policy pursued through the demonstration of willingness and capacity to act (power), sustained on an identity-based discourse with historical roots (national identity), which also appeals to domestic constituents (regime security).

The negotiations that followed the outbreak of unrest in eastern Ukraine were unable to bring the conflict to an end. The repeated violations of cease-fires led to new rounds of talks involving representatives from Ukraine, Russia, France, and Germany. These talks resulted in the so-called Minsk II agreement. The negotiation process and the final wording of the document point to three important aspects. First, Moscow pushed for constitutional revisions in Ukraine, allowing for a more decentralized organization of the country. If implemented, this will allow Moscow to maintain some influence in the eastern part of Ukraine and provide a pressure point to keep Kyiv from establishing closer ties with NATO (see, e.g., Götz 2015; Robinson 2016: 507). Second, the document states that Kyiv has to negotiate with the rebels in the east. This was not readily accepted by the Ukrainian government as it would imply a de facto recognition of the rebels' authority. Nevertheless, Russia and the West have pushed the Ukrainian government in this direction. Third, it is noteworthy that Russia has demonstrated its engagement with the Minsk II provisions and, at different moments, has pressured the rebels to negotiate (see Robinson 2016). This indicates that Moscow wants to avoid uncontrolled groups and militias in these regions from pursuing their own agendas. Moscow has, in fact, gradually appointed Russian military officials to key positions in the rebel regions. The elections organized on November 4, 2014, in the self-declared Donetsk and Luhansk People's Republics (The Guardian 2014b; BBC News 2014) led to the leadership of Aleksandr Zakharchenko and Igor Plotnitsky, respectively. According to Robinson (2016: 514), this was essential for the successful conclusion of the Minsk II negotiations. Nevertheless, the agreement has so far failed to bring peace as none of the parties is fully complying with its provisions.

It is also important to note that Moscow's actions vis-à-vis Ukraine have not been without costs for Russia itself. For one thing, Russian actions and justifications were fiercely criticized by the West. The USA and many European countries considered the annexation of Crimea an illegitimate and illegal act, violating not only the Ukrainian Constitution (art.73 states that any secession referendum must have the consent of the whole people of Ukraine) but also international legislation. Thus, events in Ukraine contributed to augment the divide between Russia and the EU (see, e.g., MacFarlane and Menon 2014; Gretskiy et al. 2014).

Furthermore, by annexing Crimea, Putin played the identity card, but subsequent developments made clear that this move proved counterproductive, given the proWestern orientation of large swathes of the Ukrainian population. Indeed, as Marten (2015) points out, Russia's actions ended up bringing Ukraine closer to NATO, 
instead of keeping it in Moscow's orbit. In particular, 'by taking Crimea's predominantly Russian ethnic voters out of Ukraine, he [Putin] lost a political tool of influence that Russia had long held in Kyiv' (Marten 2015: 190). This means that in the process, Russia distanced itself from both Ukraine and the West. The conclusion of the Association Agreement and DCFTA between the Ukrainian authorities and the EU signaled this loss. In the words of Charap and Darden (2014: 12), 'Gaining Crimea to lose Ukraine just did not seem like a rational trade-off.'

Finally, the reintegration of Crimea is costly for Russia in economic terms. This is particularly challenging given the prolonged low in oil prices on international markets. The sanctions that the USA and EU-Europe imposed on Russia have contributed not only to negatively affect its economic situation, but also to isolate Russia further from the West (Freire and Heller 2018). This does not augur well for overcoming difficulties in Russian relations with the West (Haukkala 2016). It also does not bode well for the affirmation of Russian great-power status that Moscow seeks.

\section{Eurasian Economic Union: Russia in, Ukraine out}

Given Russia's generally difficult economic situation, it needs multilateral projects like the Eurasian Economic Union (EEU) to foster trade and eventually promote the diversification of its economy. However, side-by-side with economic considerations, there are three convergent political goals associated with this initiative. First, Russia aims at keeping a visible presence in its geographical neighborhood. The goal is to assure influence as well as limit Western promotion of institutional formats in the post-Soviet space. Second, regime security plays an important role in Russia's drive for integration, including economic growth and investment in key economic areas, which are fundamental for maintaining public support for the regime. This was made clear by Putin in his annual news conference that took place on December 14, 2017 (President of Russia 2017b). Third, the EEU is part of a broader project of Eurasian integration, which could promote Russia's 'great power image' in this space. Indeed, the official discourse underlining this project emphasizes its constitutive identitarian roots. Back in 2013, for example, Putin stated that the combination of convergent national identities of prospective member states reinforced the EEU. At the time, he also referred to the 'historical Eurasian space' and added that the integration process provided the opportunity for the EEU 'to become an independent center for global development, rather than remaining on the outskirts of Europe and Asia' (Putin cited in Svarin 2016: 137). In short, a combination of economic and domestic political considerations (domestic growth as part of regime stability), along with geopolitical and ideational motivations, underpin Russia's efforts to create the Eurasian Economic Union.

However, the problems that characterize Russia's relations with other post-Soviet republics create difficulties for the promotion of Moscow's integrationist agenda. In fact, most of these countries are not eager to join a Russia-dominated bloc. Instead, many of them seek to develop (sometimes quite explicitly) multi-vectoral diplomacies that conceptually challenge the premises of spheres of influence (Freire 2016: 
37). The case of Ukraine is indicative of how Russia's actions led to unintended and unfavorable consequences, not least with regard to the EEU project. The choice that President Yanukovych had to make between signing a customs union with common external tariffs with the EEU or a free trade arrangement with the EU became a turning point in Ukraine. At first, Yanukovych seemed inclined to sign the agreement with the EU, but abandoned this plan in autumn 2013 in favor of siding with the Russian proposal. After the ousting of Yanukovych, however, Kyiv opted for association with the EU.

For Russia, as indicated above, the EEU is not only an economic project (with domestic and international impact), but it is also part of Russia's projection of power into an area-the post-Soviet space - that it considers to be of vital importance and where it shares historical bonds. It is in this way part of Russia's policy to reinforce its international status. In other words, the creation of the EEU can be understood as an attempt to 'counterbalance' the EU (The Moscow Times 2015), while at the same time furthering the geopolitical and ideational integration in Eurasia.

The fact that Ukraine is now absent from this format brings fragility to the overall process. Kyiv's signing of the EU Association Agreement and DCFTA in March and June 2014, respectively, exacerbated the rift between Ukraine and Russia (Kirkham 2016: 122). It also constituted a setback for Russia's policy of further integration in the post-Soviet space. In this context, it is also interesting to note Armenia's change of course in 2013. At first, Yerevan was prepared to sign the Association Agreement with the EU, scheduled for November 2013, but then decided in favor of the country's integration into the EEU. In September 2013, Armenian President Serge Sargsyan commented that it was 'a rational decision stemming from the national interests of Armenia,' adding that dialogue with European structures would continue (cited in RFE/RL 2013). This change in course was widely interpreted as resulting from Russian pressure through energy and trade (Zahorca and Sargsyan 2014: 94), which the Armenian president recognized implicitly in his remarks.

By employing economic and political pressure and using coercive means, Russia ended up including Armenia in the EEU, while pushing away Ukraine from any further integration. It should also be noted here that Armenia signed a Comprehensive and Enhanced Partnership Agreement (CEPA) with the EU on November 24, 2017 (EEAS 2017), keeping open its door to the West. These developments have contributed to a 'zero-sum' reading of regional dynamics (Cadier and Charap 2017: 12), where integration around Russia has been increasingly limited. In fact, as Cadier and Charap (2017: 12) point out,

by attempting to turn the EEU into a foreign policy instrument, Moscow has been undermining its own creation. Armenia was pressured into joining but has been an unenthusiastic member, while Kyrgyzstan was allowed to join in spite of its weak economy and porous border with China. Russia's attempt to politicize the EEU triggered the resistance of Belarus and Kazakhstan: they rejected, for instance, its demand to impose common trade sanctions on the West and Ukraine. More crucially, Russia's intervention in Ukraine increased Belarus' sensitivity about its political sovereignty, and thus decreased its disposition towards economic integration. 
In essence, the success of Russia's attempt to gain status recognition through its project of regional integration in the post-Soviet space has been limited at best. Power politics played both ways, pushing Armenia closer to Russia but pushing Ukraine away. National identity as a driver to fostering common bonds in the Eurasian space was part of the political rhetoric but, to a large extent, it was subordinated to power politics in this case.

\section{Georgia: rewinding and fast-forwarding the 2008 war implications}

Russian foreign policy toward Georgia is also illustrative of the quest for status and the interplay of power politics, identity, and regime security that underpins it. After Georgian actions in the summer of 2008, when it moved military forces across the 'border' with South Ossetia, Russia took advantage of the opportunity to demonstrate its power and assert its influence in the former Soviet space. By intervening militarily in August 2008, Moscow demarcated the lines concerning areas of influence; it weakened Georgia whose pro-Western course had long been regarded as provocative by the Russian leadership; and it sought to contain the West's and especially NATO's influence in the South Caucasus. The subsequent conclusion of comprehensive security-military and economic treaties with Abkhazia and South Ossetia has demonstrated Russia's resolve in controlling these territories and not ceding on the post-2008 status quo. Once more, the geopolitical dimension is very much present in Russian foreign policy actions, which were justified largely by normative considerations of rights' violations, and which benefited from broad-based domestic support in Russia.

The events of summer 2008 in the South Caucasus must be analyzed in the context of the pro-Western presidency of Saakashvili after the 'Rose Revolution' that marked a change in Georgian politics. The issue of reintegration of the breakaway regions of Abkhazia and South Ossetia became a top priority on President Saakashvili's agenda. Thus, after several rounds of negotiations had failed, Georgian forces launched an operation in Tskhinvali in the night of August 7, 2008. Russia responded, and in 5 days, it had forced the withdrawal of Georgian forces from South Ossetia and occupied previously uncontested Georgian territory. Talks for a cease-fire agreement were hosted by then French President Nicolas Sarkozy (in charge of the rotating presidency of the European Council) on August 15 and 16, leading to the conclusion of an agreement in Tbilisi and Moscow, respectively (Six Point Peace Plan 2008). According to this six-point plan, Russia had to withdraw from Georgian territory in October, and the EU would send a Monitoring Mission to oversee movements along the administrative boundary line separating Georgia from the territory of South Ossetia. But talks on 'security and stability arrangements for Abkhazia and South Ossetia,' as foreseen in the last point of the agreement, quickly stalled. There was no willingness of the Georgian authorities to negotiate with the separatists.

Undoubtedly, the five-day war projected Russia's status internationally. Through military intervention, it showed the resolve to act; through recognition of Abkhazia and South Ossetia as independent states, it showed the power to interfere; and 
through a discourse on Russian minorities' rights, it showed a normative drive that emphasized national identity matters. After the war, moreover, Moscow concluded a number of political and security treaties with the two separatist entities.

On September 17, 2008, Russia signed Treaties on Friendship, Cooperation and Mutual Assistance with Abkhazia and South Ossetia including provisions of military support from Russia to these territories. In this way, the recognition of these two republics was formalized. Additionally, in April 2009, then Russian President Medvedev signed cooperation agreements with both Abkhazia and South Ossetia regarding the protection of borders and coordination of state security services against 'acts of aggression, terrorism or cross-border crime' (President of Russia 2009). Western countries voiced criticisms, stressing the need to respect Georgia's sovereignty as well as the violation of the six-point agreement of August 2008-to no avail (EUObserver 2009). Russia signed further defense treaties with South Ossetia and Abkhazia, committing itself to defend them from any attempt by the Georgian authorities to change the new status quo (Driscoll and Maliniak 2016: 596). Russia stepped up its security cooperation with the separatist regions in November 2014, when President Putin signed with the Abkhaz leader Raul Khadzhimba an agreement foreseeing a new joint force of Russian and Abkhaz troops, as well as the harmonization in security and defense policies. In parallel, Moscow granted an additional $\$ 270$ million in subsidies for a period of 3 years, for pensions and social benefits, thus reinforcing the security agenda with substantial economic support. Khadzhimba commented at the time that 'ties with Russia offer us full security guarantees' (The Guardian 2014a; Reuters 2014b). In February 2015, Moscow concluded a Strategic Partnership Treaty with Abkhazia, implying further cooperation on social, economic and humanitarian grounds, as well as envisaging the establishment of a defense and security space where Abkhaz and Russian troops come together under a unified command (RFE/RL 2015). A separate treaty on the establishment of a Joint Group of Armed Forces of the Russian Federation and the Republic of Abkhazia was signed in November 2015 and was ratified by Russia one year after (President of Russia 2016).

In March 2015, Russia and South Ossetia's leader Leonid Tibilov signed a new treaty envisaging deep economic and military integration, according to which provisions Russia would be in charge of controlling the border, as well as the region's economy and armed forces. The treaty also envisaged the easing of procedures to grant Russian citizenship to South Ossetians. In his subsequent announcement, Putin claimed that this would create a 'joint defense and security zone' between South Ossetia and Russia and would keep border crossings open 'for our citizens.' Unsurprisingly, Georgian and Western leaders were highly critical of the treaty. Taking place one year after the takeover of Crimea, Western media outlets described it as opening a path for Russia's annexation of South Ossetia (The Independent 2015). In March 2017, moreover, Moscow approved a new military agreement, according to which some units of South Ossetia's forces will be integrated into the Russian army. This move allows South Ossetia to maintain its own military forces, while placing some of its units under Russian control (Aljazeera 2017). From Moscow's point of view, it assures 'reliable protection against external aggression' (Jamestown.org 2017). In sharp contrast, the Georgian Foreign Affairs Minister Mikheil Janelidze 
called the agreement 'an actual annexation (...) undermining regional security' (Jamestown.org 2017; see also Georgia Today 2017). Russia has also been accused of taking control of additional Georgian territory by changing the border demarcation without any previous consultations and in violation of standing agreements (see RFE/RL 2017a, b).

The above-described treaties reveal the need Russia feels to keep these regions under its control. In fact, the economic, social, and infrastructure conditions are frail in both Abkhazia and South Ossetia, and corruption has diverted part of the investment funds coming from Russia. To some extent, corrupted local leaders serve Russian interests (Orttung and Walker 2015). But local mismanagement also contributes to instability. Dissatisfaction with the situation has led to unrest in these territories, for example, with rising crime and internal political rifts challenging the security and political situation there (RFE/RL 2017d). This has pushed Russia to step up its effective control over these territories to avoid uncontrolled unrest, which would directly impinge upon its international agenda, as well as upon its domestic affairs. This links clearly to the regime security dimension. Russia seeks to prevent a 'colorful revolution' in these two territories as well as in the post-Soviet space more generally.

Identity matters also play an important role. Consider, for instance, the referendum that was held in South Ossetia in February 2017 on the official name of the republic, with more than 80 percent of the voters agreeing to a change in designation of the country to Republic of South Ossetia-the State of Alania. ${ }^{3}$ This proposed name change is important, as it highlights the ethnic and historic linkages with North Ossetia-Alania Republic. What is more, it sets apart the State of Alania from other North Caucasian republics, underlining a strong past legacy of integration with Russia (RFE/RL 2017c). This could signify an attempt by the South Ossetian leadership at eventual reunification with Russia in the not-too-distant future. Nevertheless, Moscow's reaction to these developments has been cautious. In November 2017, summing up bilateral talks between Russia and South Ossetia, President Putin commented that 'Russia supports South Ossetia in becoming a sovereign democratic state, as it supports its security,' clearly distancing itself from a unification scenario (President of Russia 2017a). Thus, Moscow has resisted embarking upon a policy of outright annexation, which has obvious downsides as discussed earlier with regard to the case of Crimea.

In essence, the control of the economic and security agendas of both Abkhazia and South Ossetia, side-by-side with a discourse on 'our citizens' and the facilitation of procedures to allow for Russian citizenship, clearly demonstrates Russia's drive for assuring a no-return policy in these territories. This serves the purpose of showing Russia's willingness and capacity to act in an area that has become strategically important in an increasingly heterogeneous neighborhood, built on a rights-to-berespected discourse.

\footnotetext{
${ }^{3}$ To this day, the new designation has not been officially adopted.
} 


\section{Conclusion}

Russia's status-seeking aspirations have become increasingly assertive. Moscow seems committed to defend its interests in the so-called 'near abroad' by resorting to the use of force, if required. However, this does not necessarily mean that Russia is ready to engage in a post-imperialist territorial conquest in the post-Soviet space. Despite the annexation of Crimea and the large number of military-security treaties, Moscow has signed with Abkhazia and South Ossetia, which assure extended Russian control over these territories, there are indications that the goal is to avoid changes to the post-2008 status quo in Georgia. Likewise, the policy of destabilizing parts of eastern Ukraine and the efforts at further control of separatist groups operating in the area show Russia's perceived need to maintain some form of control over developments there. At the same time, Moscow does not evince any political will to integrate these territories into the Russian Federation.

These moves attest to the core elements that underpin Russia's status-seeking foreign policy, which is driven by the geopolitical relevance of its neighborhood, the identity-based considerations that have been very much present in political justifications based on ethnic-solidarity and rights' protection of Russian minorities abroad, and the gathering of domestic support. Given the difficult economic situation Russia currently faces, as the country is still recovering from a recession, it could prove difficult to keep domestic audiences satisfied with an assertive and interventionist course. However, by couching these actions in terms of a normative and ideational discourse about the neighborhood and feeding geopolitical narratives about the 'Western other,' Moscow continues to generate domestic support for its 'near abroad' policy and the regime more generally.

To conclude, status recognition remains central in Russian foreign policy, but looking at it from an exclusive geopolitical, ideational or domestic political angle is limiting. As this analysis shows, Russia's status ambitions are partly driven by power politics, partly by identity-related issues, and partly by regime security considerations. This analysis has also shown that Russia's status-seeking strategy to obtain a stronger position in its neighborhood has led to dilemmas and unintended consequences. In fact, the immediate gains from the war in Georgia and the annexation of Crimea have proved costly in Russia's relations with some of its neighbors as well as with the West. Regarding the former, Russia effectively pushed away Georgia and Ukraine by promoting nationalist feelings in these republics, by fueling anti-Russian rhetoric at the political level, and by reinforcing the willingness of these countries to pursue integration with the West. On the latter, sanctions have become the symbol of disconnection between Russia and the West, while at the same time exacerbating the rift and contributing to Russia's isolation from Euro-Atlantic institutional structures. 


\section{References}

Ademmer, E., L. Delcour, and K. Wolczuk. 2016. Beyond Geopolitics: Exploring the Impact of the EU and Russia in the 'contested neighborhood'. Eurasian Geography and Economics 57(1): $1-18$.

Aljazeera. 2017 Putin Approves Army Deal with Georgia’s South Ossetia. 14 March, http://www. aljazeera.com/news/2017/03/putin-approves-army-deal-georgia-south-ossetia-170314154927196 .html. Accessed 27 Oct 2017.

Ambrosio, T. 2005. Challenging America's Global Prominence-Russia's Quest for Multipolarity. Basigstoke: Ashgate.

BBC News. 2014. Why are Ukraine Separatist Elections Controversial? 1 November. http://www.bbc. com/news/world-europe-29831028. Accessed 27 Oct 2017.

Berryman, J. 2014. 'Fear and Loathing' in the Kremlin: Russia and the Challenge of Intervention. In Shifting Priorities in Russia's Foreign and Security Policy, ed. R.E. Kanet, and R. Piet, 51-72. London: Routledge.

Cadier, D., and S. Charap. 2017. The Polarisation of Regional Politics: The Impact of the EU-Russia Confrontation on Countries the Common Neighbourhood. In Damage Assessment: EU-Russia Relations in Crisis, ed. Ł. Kulesa, I. Timofeev, and J. Dobbs, 9-16. Moscow: Special Report, European Leadership Network and Russian international Affairs Council (RIAC).

Charap, S., and K. Darden. 2014. Russia and Ukraine. Survival 56(2): 7-14.

Driscoll, J., and D. Maliniak. 2016. With Friends like these: Brinkmanship and Chain-Ganging in Russia's Near Abroad. Security Studies 25(4): 585-607.

EEAS. 2017. New Agreement Signed Between the European Union and Armenia Set to Bring Tangible Benefits to Citizens. Press Release, 24 November. https://eeas.europa.eu/headquarters/headq uarters-homepage/36141/new-agreement-signed-between-european-union-and-armenia-set-bring -tangible-benefits-citizens_en. Accessed 10 Jan 2018.

EUObserver. 2009 EU Condemns Russian Agreement with South Ossetia, Abkhazia. 1 May. https:// euobserver.com/news/28051. Accessed 27 Oct 2017.

Evangelista, M. 1997. Domestic Structure and International Change. In New Thinking in IR Theory, ed. M. Doyle, and G.J. Ikenberry, 203-228. Boulder, CO: Westview Press.

Forsberg, T., and C. Pursiainen. 2017. The Psychological Dimension of Russian Foreign Policy: Putin and the Annexation of Crimea. Global Society 31(2): 220-244.

Freire, M.R. 2011. USSR/Russian Federation Major Power Status Inconsistencies. In Major Powers and the Quest for Status in International Politics: Global and Regional Perspectives, ed. T. Volgy, R. Corbetta, K.A. Grant, and R.G. Baird, 55-76. New York: Palgrave Macmillan.

Freire, M.R. 2016. Russian Foreign Policy and the Shaping of a 'greater Europe'. In Security in Shared Neighbourhoods: Foreign Policy of Russia, Turkey, and the EU, ed. R. Piet, and L. Simão, 35-52. London: Palgrave Macmillan.

Freire, M.R., and R. Heller. 2018. Russian power politics in Ukraine and Syria-status-seeking between identity, opportunity and costs. Europe-Asia Studies (forthcoming).

Freire, M.R., and L. Simão. 2018. EU-Russia Relations and the Unravelling of the European Security Regime in the Context of the Ukraine Crisis. In EU-Russia Relations in Crisis. Understanding Divergent Perspectives, ed. T. Casier, and J. DeBardeleben, 159-177. London: Routledge.

Georgia Today. 2017. Russia Absorbs Military Units of Breakaway Abkhazia. 3 April. http://georg iatoday.ge/news/6244/Russia-Absorbs-Military-Units-of-Breakaway-Abkhazia. Accessed 27 Oct 2017.

Götz, E. 2015. It's Geopolitics, Stupid: Explaining Russia's Ukraine Policy. Global Affairs 1(1): 3-10.

Gretskiy, I., E. Treshchenkov, and K. Golubev. 2014. Russia's Perceptions and Misperceptions of the EU Eastern Partnership. Communist and Post-Communist Studies 47: 375-383.

Haukkala, H. 2016. A Perfect Storm; or What Went Wrong and What Went Right for the EU in Ukraine. Europe-Asia Studies 68(4): 653-664.

Hill, C. 2003. The Changing Politics of Foreign Policy. Basingstoke: Palgrave MacMillan.

Jamestown.org. 2017. Russian Military Absorbs 'Army of South Ossetia. 21 March. https://james town.org/program/russian-military-absorbs-army-south-ossetia/. Accessed 27 Oct 2017.

Kirkham, K. 2016. The Formation of the Eurasian Economic Union: How Successful is the Russian Regional Hegemony? Journal of Eurasian Studies 7: 111-128. 
Levada Centre. 2017. Vladimir Putin's Work: How Would You Rate Vladimir Putin's Work as President of Russia? 11 December. https://www.levada.ru/en/2017/12/11/vladimir-putin-s-work/. Accessed 10 Jan 2018.

MacFarlane, N., and A. Menon. 2014. The EU and Ukraine. Survival 56(3): 95-101.

Manning, B. 1977. The Congress, the Executive and Intermestic Affairs: Three Proposals. Foreign Affairs 55(2): 306-324.

Marten, K. 2015. Putin's Choices: Explaining Russian Foreign Policy and Intervention in Ukraine. The Washington Quarterly 38(2): 189-204.

Mearsheimer, J. 2014. Why the Ukraine Crisis is the West's Fault: The Liberal Delusions that Provoked Putin. Foreign Affairs 93(5): 77-89.

Neack, L. 2008. The New Foreign Policy. Power Seeking in a Globalized Era. 2nd ed. Lanham, Boulder: Rowman and Littlefield Publishers.

Neumann, I.B. 2008. Russia as a Great Power, 1815-2007. Journal of International Relations and Development 11(2): 128-151.

Orttung, R. and Walker, C. 2015. Putin's Frozen Conflicts. Foreign Policy. 13 February. http://foreignpol icy.com/2015/02/13/putins-frozen-conflicts/. Accessed 27 Oct 2017.

President of Russia. 2009. Speech at Ceremony for Signing Bilateral Documents Between the Russian Federation, the Republic of Abkhazia and the Republic of South Ossetia. The Kremlin, Moscow. 30 April. http://en.kremlin.ru/events/president/transcripts/3921. Accessed 27 Oct 2017.

President of Russia. 2016. Law on Ratification of Russia-Abkhazia Agreement on Joint Group of Forces. The Kremlin, Moscow. 22 November. http://en.kremlin.ru/acts/news/53291. Accessed 27 Oct 2017.

President of Russia. 2017a. Press Statements Following Russia-South Ossetia talks. 14 November. http:// en.kremlin.ru/events/president/news/56075. Accessed 15 Nov 2017.

President of Russia. 2017b. Vladimir Putin's Annual News Conference. 14 December. http://en.kreml in.ru/events/president/news/56378. Accessed 10 Jan 2018.

Putin, V. 2014. Address by President of the Russian Federation to State Duma deputies, Federation Council Members, Heads of Russian Regions and Civil Society Representatives in the Kremlin. Moscow. 18 March. http://en.kremlin.ru/events/president/news/20603. Accessed 27 Oct 2017.

Putnam, R.D. 1988. Diplomacy and Domestic Politics: The Logic of Two-Level Games. International Organization 42(3): 427-460.

Reuters. 2014a. Crimeans Vote Over 90\% to Quit Ukraine for Russia. 16 March. https://www.reute rs.com/article/us-ukraine-crisis/crimeans-vote-over-90-percent-to-quit-ukraine-for-russia-idUSB REA1Q1E820140316. Accessed 27 Oct 2017.

Reuters. 2014b. Putin Strengthens Ties with Georgia Breakaway Region; Tbilisi Protests. 24 November. https://www.reuters.com/article/us-russia-georgia-abkhazia/putin-strengthens-ties-with-georgiabreakaway-region-tbilisi-protests-idUSKCN0J81KI20141124. Accessed 27 Oct 2017.

RFE/RL. 2013. Armenia To Join Russian-Led Customs Union. 3 September. https://www.rferl.org/a/ armenia-customs-union/25094560.html. Accessed 27 Oct 2017.

RFE/RL. 2015. Putin Signs Law Ratifying Russia-Abkhazia Strategic Partnership Treaty. 4 February. https://www.rferl.org/a/putin-law-abkhazia-georgia-treaty-south-ossetia-agreement-tibilov/26829 932.html. Accessed 27 Oct 2017.

RFE/RL. 2017a. Georgian Activists Warned Not to Patrol Contact Lines with Breakaway Regions. 26 July. https://www.rferl.org/a/georgia-activisits-warned-contact-lines-breakaway-regions/28639084. html. Accessed 27 Oct 2017.

RFE/RL. 2017b. Georgians Protest Moving of South Ossetia Boundary. 14 July. https://www.rferl.org/a/ georgians-protest-moving-of-south-ossetia-boundary/28616844.html. Accessed 27 Oct 2017.

RFE/RL. 2017c. South Ossetia's Bibilov Wins Election, Puts Moscow in a Bind. 11 April. https://www. rferl.org/a/south-ossetia-bibilov-victory-presidential-election/28424108.html. Accessed 27 Oct 2017.

RFE/RL. 2017d. Abkhazia Heads Into New Political Crisis. 10 July. https://www.rferl.org/a/caucasusreport-abkhazia-heads-into-new-political-crisis/28606813.html. Accessed 27 Oct 2017.

RFP. 2000. The Foreign Policy Concept of the Russian Federation. Approved by Vladimir Putin, President of the Russian Federation. 28 June. http://fas.org/nuke/guide/russia/doctrine/econcept.htm. Accessed 27 Oct 2017.

RFP. 2008. The Foreign Policy Concept of the Russian Federation. Approved by Dmitry A. Medvedev, President of the Russian Federation. 12 July. http://archive.kremlin.ru/eng/text/docs/2008/07/20475 0.shtml. Accessed 27 Oct 2017. 
RFP. 2013. Concept of the Foreign Policy of the Russian Federation, Approved by President of the Russian Federation V. Putin. http://archive.mid.ru//brp_4.nsf/0/76389FEC168189ED44257B2E0039B1 6D. Accessed 27 Oct 2017.

RFP. 2016. Foreign Policy Concept of the Russian Federation (Approved by President of the Russian Federation Vladimir Putin on November 30, 2016). 1 December. http://www.mid.ru/en/foreign_policy/ official_documents/-/asset_publisher/CptICkB6BZ29/content/id/2542248. Accessed 27 Oct 2017.

Robinson, P. 2016. Russia's role in the war in Donbass, and the threat to European security. European Politics and Society 17(4): 506-521.

Russian Military Doctrine. 2014. Approved by the President of the Russian Federation on December 25, No. Pr.-2976. 29 June. http://rusemb.org.uk/press/2029. Accessed 27 Oct 2017.

Saideman, S.M., and R.W. Ayres. 2007. Pie Crust Promises and the Sources of Foreign Policy: The Limited Impact of Accession and the Priority of Domestic Constituencies. Foreign Policy Analysis 3(3): 189-210.

SIPRI Report on World Military Spending. 2017 World Military Spending: Increases in the USA and Europe, Decreases in Oil-Exporting Countries. 24 April. https://www.sipri.org/media/press-relea se/2017/world-military-spending-increases-usa-and-europe. Accessed 27 Oct 2017.

Six Point Peace Plan. 2008. Protocole D’accord, Présidence Française, Nicolas Sarkozy. https://franceinth eus.org/IMG/pdf/accord6points.pdf. Accessed 27 Oct 2017.

Suslov, M. 2017. The Protection of 'Novorossiya': A Territorial Brand in Public Debates. Europe-Asia Studies 69(2): 202-221.

Svarin, D. 2016. The Construction of 'geopolitical paces' in Russian Foreign Policy Discourse Before and After the Ukraine Crisis. Journal of Eurasian Studies 7: 129-140.

The Guardian. 2015. Vladimir Putin's Approval Rating at Record Levels. 23 July. https://www.theguardia n.com/world/datablog/2015/jul/23/vladimir-putins-approval-rating-at-record-levels. Accessed 27 Oct 2017.

The Guardian. 2014a. Georgia Angered by Russia-Abkhazia Military Agreement. 25 November. https ://www.theguardian.com/world/2014/nov/25/georgia-russia-abkhazia-military-agreement-putin. Accessed 27 Oct 2017.

The Guardian. 2014b. Ukraine: Donetsk Votes for New Reality in Country that Does Not Exist. 3 November. https://www.theguardian.com/world/2014/nov/02/donetsk-peoples-republic-luhansk-ukraineprime-minister-elections. Accessed 27 Oct 2017.

The Independent. 2015. Putin Signs Deal Calling for Almost Complete Integration of South Ossetia into Russia-On Anniversary of Crimea Annexation. 19 March. http://www.independent.co.uk/news/ world/europe/putin-signs-deal-calling-for-almost-complete-integration-of-south-ossetia-into-russi a-on-anniversary-10120690.html. Accessed 27 Oct 2017.

The Moscow Times. 2015. Armenia Joins Russia-led Eurasia Economic Union. 2 January. https://themo scowtimes.com/articles/armenia-joins-russia-led-eurasian-economic-union-42666. Accessed 10 Jan 2018.

Trenin, D. 2009. Russia's Spheres of Interest, not Influence. The Washington Quarterly 32(4): 3-22.

Tsygankov, A.P. 2014. The Frustrating Partnership: Honor, Status, and Emotions in Russia's Discourses of the West. Communist and Post-Communist Studies 47: 345-354.

VCIOM. 2017. Question: 'Do you generally approve or disapprove of the... ?', Russian Public Opinion Research Centre, Rating of State Institutions. 29 December. https://wciom.com/index.php?id=122. Accessed 10 Jan 2018.

Volgy, T. J., Corbetta, R., Grant, K. A. and Baird, R. G. (eds.). 2011. Major Powers and the Quest for Status in International Politics: Global and Regional Perspectives. New York: Palgrave Macmillan.

Zahorca, H., and O. Sargsyan. 2014. The Eurasian Customs Union: An Alternative to the EU's Association Agreements? European View 13: 89-96. 